\title{
PAISAGEM EM MOVIMENTO: O PARQUE ANDRÉ-CITROËN EM PARIS
}

\section{Angelo Serpa}

Professor adjunto, mestrando e doutor do Departamento de Geografia e do Programa de Pós-Graduação em Arquitetura e Urbanismo, da Universidade Federal da Bahia.

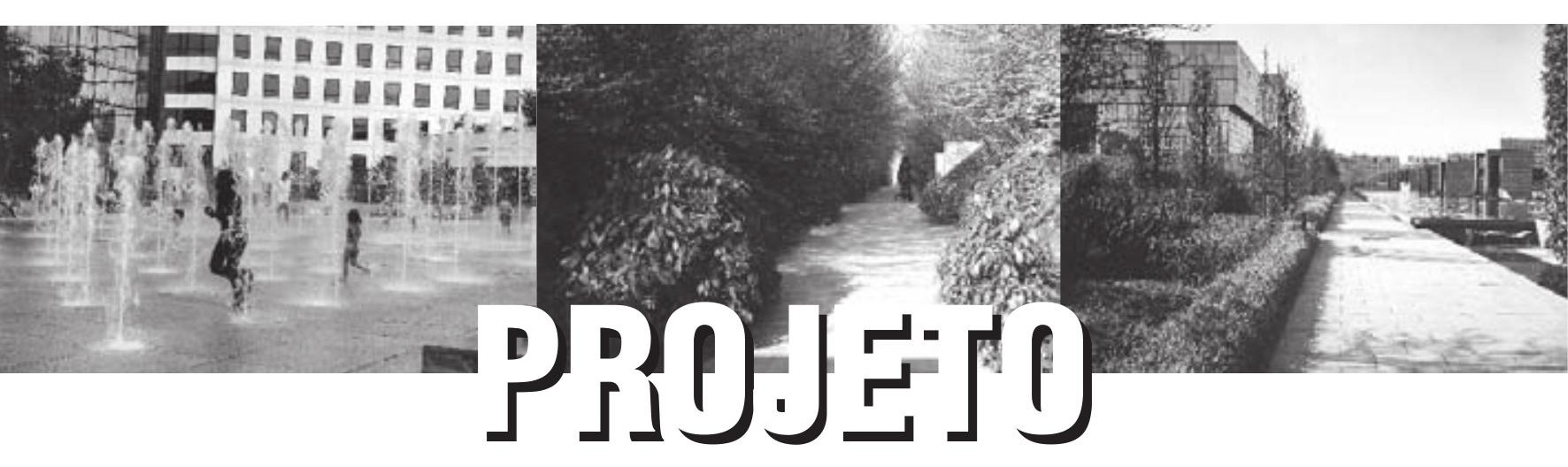




\section{RESUMO}

Neste artigo, a linguagem projetual e a utilização de parques públicos como elementos dinamizadores de operações de renovação urbana são examinadas à luz do estudo de caso do Parque André-Citroën, em Paris. A última parte do trabalho é dedicada a uma entrevista com o paisagista francês Gilles Clément, que desenhou e implantou o Jardim do Movimento no Parque André-Citroën, concebido como uma "paisagem natural", a partir de princípios ecológicos.

Palavras-chave: Parque público, renovação urbana, linguagem projetual, paisagismo, jardim.

\section{ABSTRACT}

In this paper, the designing language and the use of public parks as dynamic elements of programs for urban renovation are examined, throughout the AndréCitroën Park case study in Paris. The last part is dedicated to an interview with Gilles Clément, french landscape architect, who have designed and installed a "Jardin en Mouvement" at the André-Citroën Park, conceived as a "natural landscape", supported by ecological ideas.

Key words: Public park, urban renovation, designing language, landscape architecture, garden. 


\section{PAISAGEM EM MOVIMENTO: O PARQUE ANDRÉ-CITROËN EM PARIS'}

\section{Introdução}

Os concursos públicos organizados para criação e concepção de três grandes parques parisienses no final da década de 80, início da década de 90 (LA VILLETTE, BERCY E ANDRÉ-CITROËN), atraíram o interesse de centenas de equipes de conceptores. Os três projetos se inscrevem em um movimento de retorno ao monumental, preconizado pela arquitetura pós-moderna. Esses parques não foram concebidos apenas como "espaços verdes públicos", mas como elementos constituintes fundamentais de operações urbanísticoarquitetônicas de grande porte, substituindo áreas de perfil operário e popular da cidade por novos bairros com complexos residenciais de alto padrão e prédios comerciais e de escritórios (DEBIÉ, 1992).

Esses projetos - de arquitetos e paisagistas consagrados, premiados em concursos internacionais lançados por sociedades de economia mista, pelo estado francês ou pela prefeitura de Paris - não deixam dúvidas que os novos parques parisienses são elementos de operações urbanas de grande envergadura, visando à reestruturação de bairros inteiros. As operações urbanísticas que deram origem aos três grandes parques parisienses ao longo dos anos 90 obedecem a uma lógica comum de revalorização de áreas industriais e residenciais decadentes, transformando-as em imensos canteiros de obras denominados de "ZACs", grandes zonas de planejamento administradas por sociedades de economia mista, articulando a prefeitura ou o estado francês ao capital privado. Vistas na escala da cidade, essas intervenções continuam a ser pensadas como intervenções em um sistema urbano geral - uma rede de espaços públicos urbanos -, herdado da ação de Haussmann no século 19 (INGALINA, 1997).

Antes mesmo de tornar-se esse espaço de lazer caro aos urbanistas ávidos de natureza, o parque é uma idéia, um conceito. Concebido como equipamento urbano e recreativo, o parque público está ligado, sobretudo, a

(1) Pesquisa realizada em Paris, entre março de 2002 e março de 2003, com bolsa de pós-doutorado da Capes. 
uma vontade política. $\bigcirc$ exemplo emblemático da capital francesa mostra que, para realizar sua "utopia" de parque público, o poder real, imperial ou presidencial sempre soube buscar o auxílio de profissionais de prestígio - Lovis XIV em Versalhes: Le Nôtre et Mansart; Napoléon III para os parques de Buttes-Chaumont, de Montsouris e de Monceau: Haussmann e Alphand; François Mitterrand em la Villette: Tschumi, Gilles Vexlard (autor do Jardim das Treliças) e Alexandre Chemetoff (conceptor do Jardim dos Bambus). Trata-se, principalmente, de uma vontade política de representação no (e através do) tempo. Os parques sempre foram elementos emblemáticos de operações de urbanismo, inscritas na pequena escala espacial da aglomeração, da região, do país e do mundo.

No Buttes-Chaumont, o objetivo era o de encenar uma paisagem ideal, com uma ambigüidade própria da época em que foi concebido, na qual o falso e o verdadeiro rivalizavam "sem vergonha". Em Versalhes o parque é, sem dúvida, uma representação do poder, uma representação do mundo dominado pelo rei. Hoje, os concursos internacionais legitimam uma política voluntária de criação de grandes equipamentos culturais. $\bigcirc$ objetivo maior dessas operações revela-se por meio da criação de modelos portadores de idéias inovadoras. Essas idéias vão ajudar aos poderes públicos a representar-se na escala do mundo, assumindo riscos com relação às formas dos parques preexistentes.

Inaugurado no início dos anos 90, o Parque de La Villette já nasceu fomentando polêmica. Escolhido ao final de um concurso internacional, que contou com centenas de participantes e o paisagista brasileiro Roberto Burle Marx como presidente do júri, o projeto tirou do anonimato o arquiteto suíço Bernard Tschumi, concedendo-Ihe fama mundial. Baseado no desconstrutivismo, Tschumi quis indicar uma nova direção para o "parque do século $X X I^{\prime \prime}$. Imensos gramados, pavilhões vermelho-fogo com formas inusitadas (as Folies) e jardins temáticos vistos como "quadros de cinema" compõem o parque, entendido por seu criador como "o maior edifício descontínuo do mundo". O resultado é uma linguagem formal, só lida pelo observador que se envolver "intelectualmente" com as idéias do arquiteto inovador. Visto assim, o parque seria muito mais uma "instalação artística" que um jardim público (PROKSCH, 1992).

No Parque de Bercy - concebido por Marilène Ferrand, Jean-Pierre Feugas, Bernard Le Roy e Bernard Huet - três partes se sucedem de oeste a leste: o grande gramado, os jardins temáticos e o Jardim Romântico. Ao sul, um grande terraço às margens do Sena isola o parque da via expressa Georges Pompidou e abriga um estacionamento, locais para estocagem e manutenção, guaritas de vigilantes e sanitários públicos. Nove jardins temáticos ocupam a parte central: a horta, o observatório, o pomar, o jardim de treliças, a casa da jardinagem, o jardim de bulbos, o labirinto e o jardim dos sentidos. $\mathrm{Na}$ 
terceira parte - o Jardim Romântico - encontram-se os elementos aglutinados em torno do tema "água": canal, ilha, cascatas e gruta.

A concepção do Parque André-Citroën coube a duas equipes de conceptores: a do paisagista Gilles Clément, associado ao arquiteto Patrick Berger, e a do arquiteto paisagista Alain Provost, associado aos arquitetos Jean-Paul Viguier e Jean-François Jodry. Um caminho atravessa o parque em diagonal, ligando as partes norte e sul. Na parte central, um vasto gramado é enquadrado por belvederes de granito escuro e por rampas, fontes e cursos d'água. Duas grandes estufas de 15 metros de altura determinam a grande perspectiva sulleste. Entre as estufas, uma esplanada com jatos de água de altura variável completa o desenho "monumental" do espaço. Os jardins temáticos e seis estufas menores estão instalados ao redor do gramado central.

Como no Brasil2, em que jardins temáticos com essências nativas estão na ordem do dia e são concebidos como espaços de pequena escala em grandes parques "arquitetônicos" e minerais, que não oferecem sombra aos usuários, os parques parisienses contemporâneos são também estruturados pelos elementos construídos e não pela vegetação. Os grandes parques se tornam "transparentes" no Brasil e na França, para evitar a delinqüência e os atos de vandalismo, atividades que "apreciam a sombra cúmplice das árvores e arbustos" (LEMONIER, 1995, p. 32). Se a ausência de vegetação de médio e grande porte nos grandes parques contemporâneos parece estar em relação imediata com problemas de segurança, por outro lado, deve-se considerar o fato de a "transparência" dos parques atuais reforçar também a monumentalidade de seu desenho (desejada pelos conceptores) e torna mais evidente seu aspecto "mineral".

A concepção e implantação dos parques André-Citroën e Bercy apresentam muitos pontos em comum. Os dois parques, originados das decisões do Conselho de Paris, no início dos anos 70, deveriam contribuir para a criação de bairros, com funções residenciais, comerciais e de serviços, no lugar de antigos terrenos industriais ou de depósitos/entrepostos, próximos dos limites da cidade: as fábricas Citroën e os depósitos de vinho de Bercy e, nos dois casos, os terrenos contíguos da rede ferroviária (STARKMAN, 1993). Eles também deveriam constituir-se em equipamentos para toda a aglomeração parisiense, oferecendo aos bairros vizinhos espaços atrativos de lazer e recreação, assim como uma nova identidade que contribuísse para sua valorização (STARKMAN, op. cit.).

(2) A pesquisa de pós-doutorado procurou comparar os estudos de caso em Paris, com a concepção e implantação dos parques públicos em Salvador, na mesma década. $\bigcirc$ presente artigo, no entanto, não trata dos estudos de caso na capital baiana, objeto de análise de outros trabalhos já publicados (Ver, por exemplo: SERPA, 2003). 


\section{O Parque André-Citroën e "Seu" Bairro}

No bairro de Javel-Citroën (área total reurbanizada de 32 hectares), além do parque de 14 hectares (Foto 1), surgem 2.400 apartamentos (Fotos 2 e 3), uma superfície de escritórios e comércio de 11 hectares, um hospital (Foto 4), duas escolas, um colégio, duas creches, um ginásio e duas salas de esporte, uma biblioteca (Foto 5) e um clube para jovens, uma agência dos correios, ateliês para artistas, assim como um importante pólo audiovisual que inclui as sedes da France Télévision, do Canal Plus e da Eutelsat (Fotos 6 e 7).

Para o Parque André-Citroën, implantado nos terrenos das antigas fábricas da firma automobilística, a exigência fundamental do Ateliê Parisiense de Urbanismo e da prefeitura de Paris era o de tratar esse novo espaço público da cidade em duas escalas diversas de inserção no tecido urbano: uma correspondente à escala da aglomeração e dos grandes espaços verdes de Paris, outra concernente à escala do bairro e do distrito. Os criadores foram incentivados a conceber programas e subespaços a partir de temas originais que respeitassem também as prescrições de tratamento do entorno construído. Dez equipes foram selecionadas entre as 65 participantes do concurso (das quais 45 estrangeiras). Ao final do concurso, duas equipes foram laureadas: Viguier, Jodry e Provost, de um lado, e Berger e Clément, de outro lado. Para o projeto final, as duas equipes passaram a trabalhar juntas, com vista à conciliação de seus "discursos".

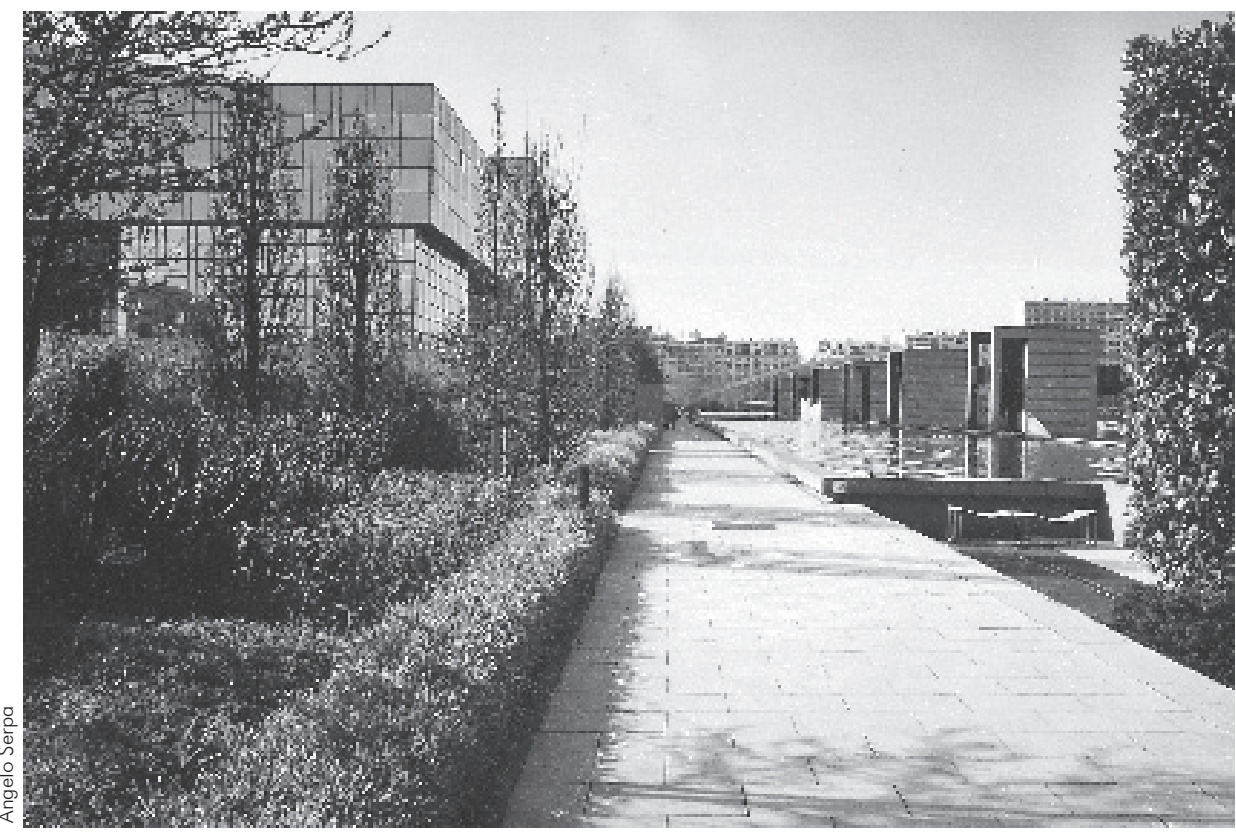

Foto 1: Parque André-Citroën, Paris 
Fotos 2 e 3: Novos prédios residenciais em Javel-Citroën
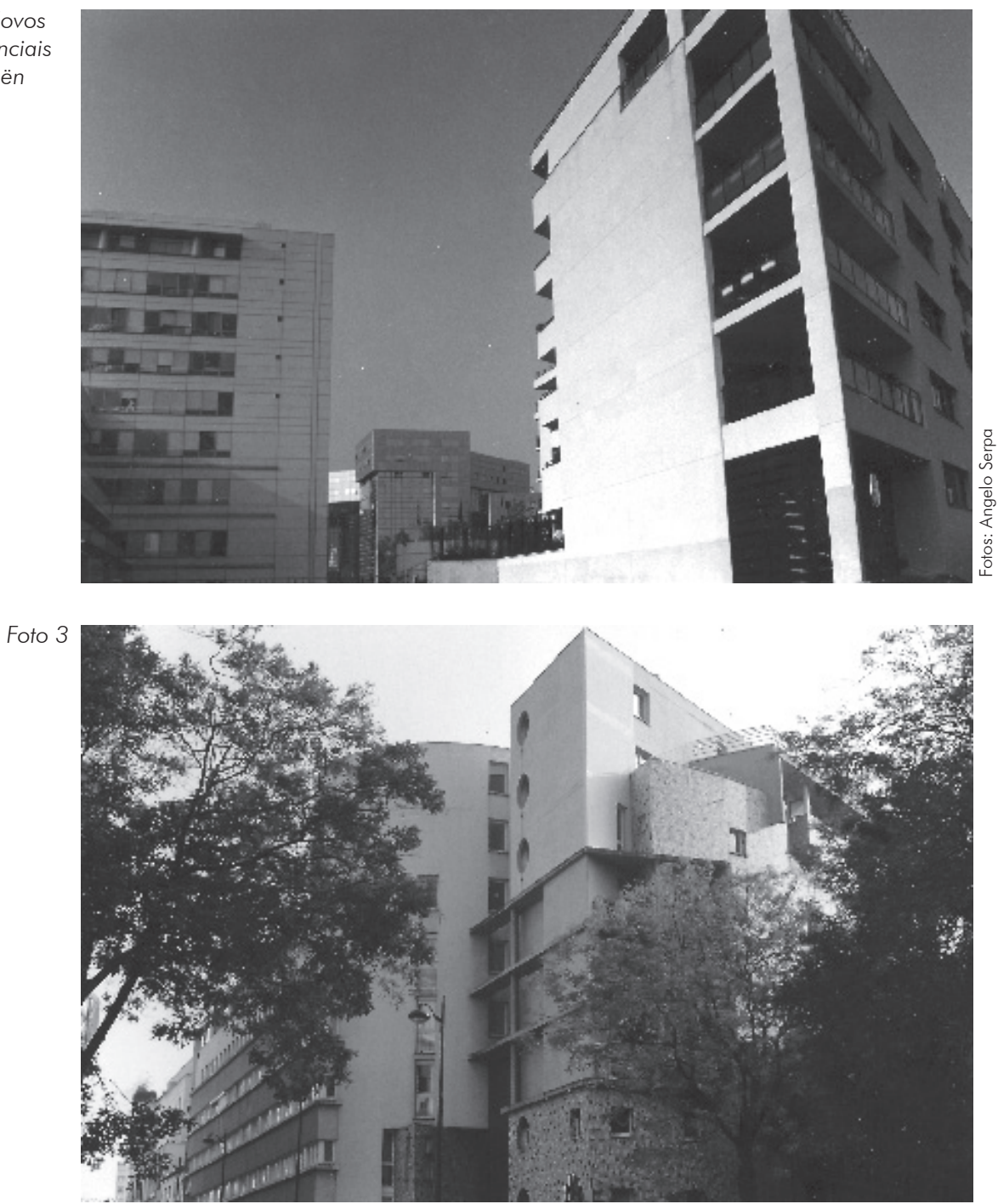

Foto 4: Hospital Georges Pompidou

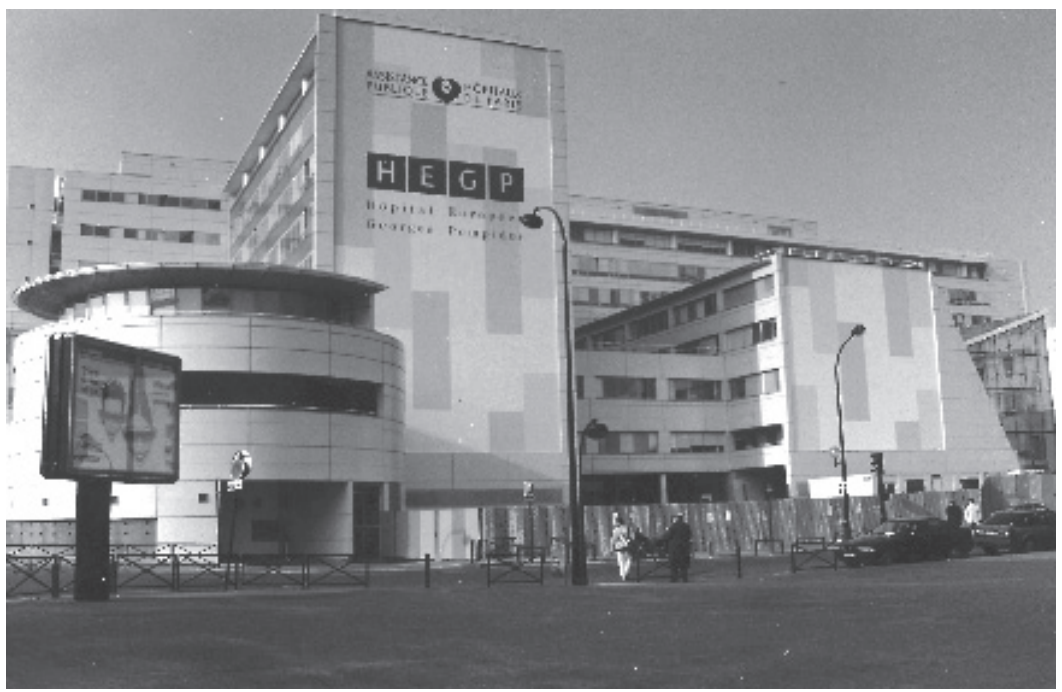




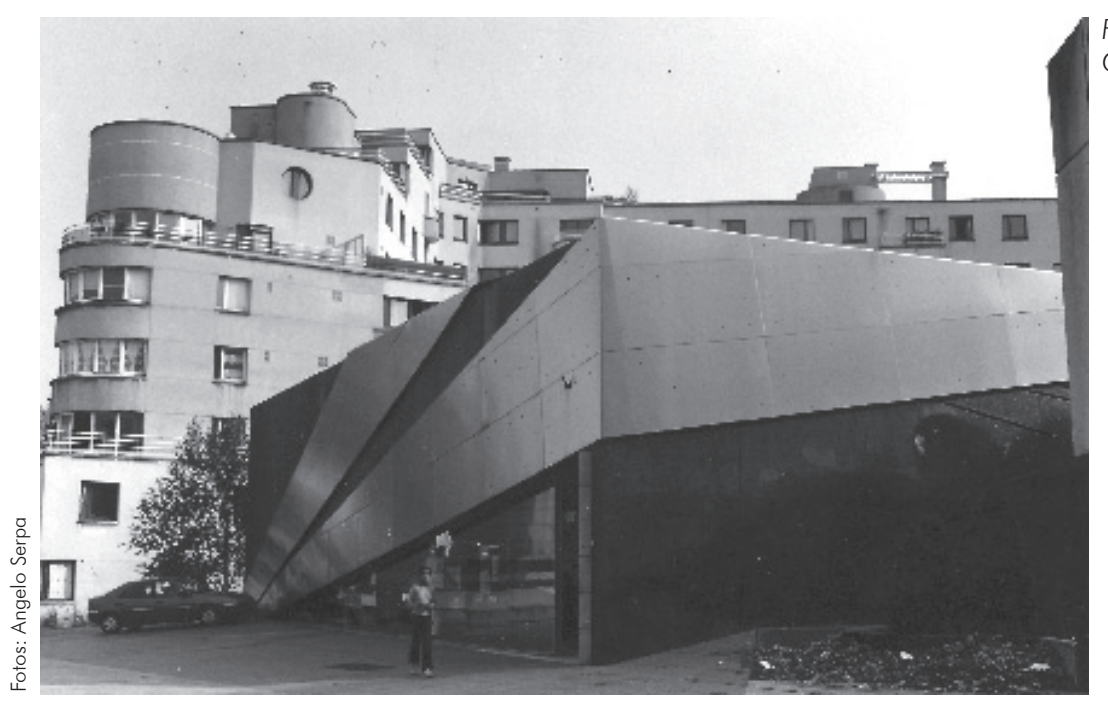

Foto 5: Biblioteca

Gutemberg

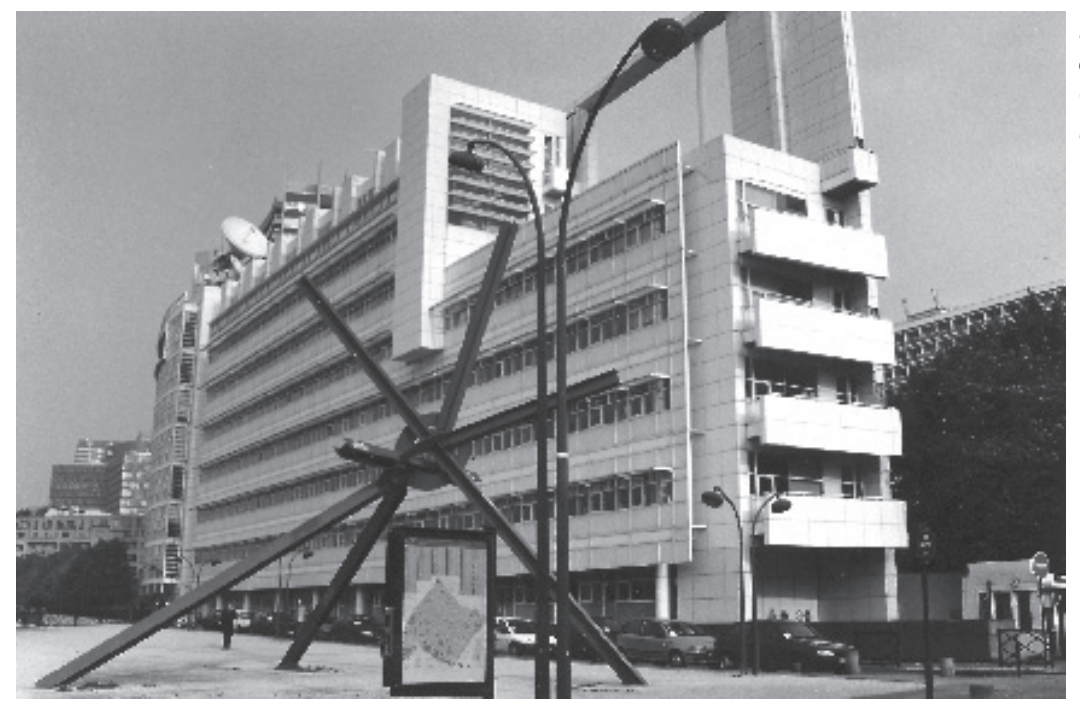

Fotos 6 e 7: Pólo audiovisual em JavelCitroën: Canal Plus e Eutelsat

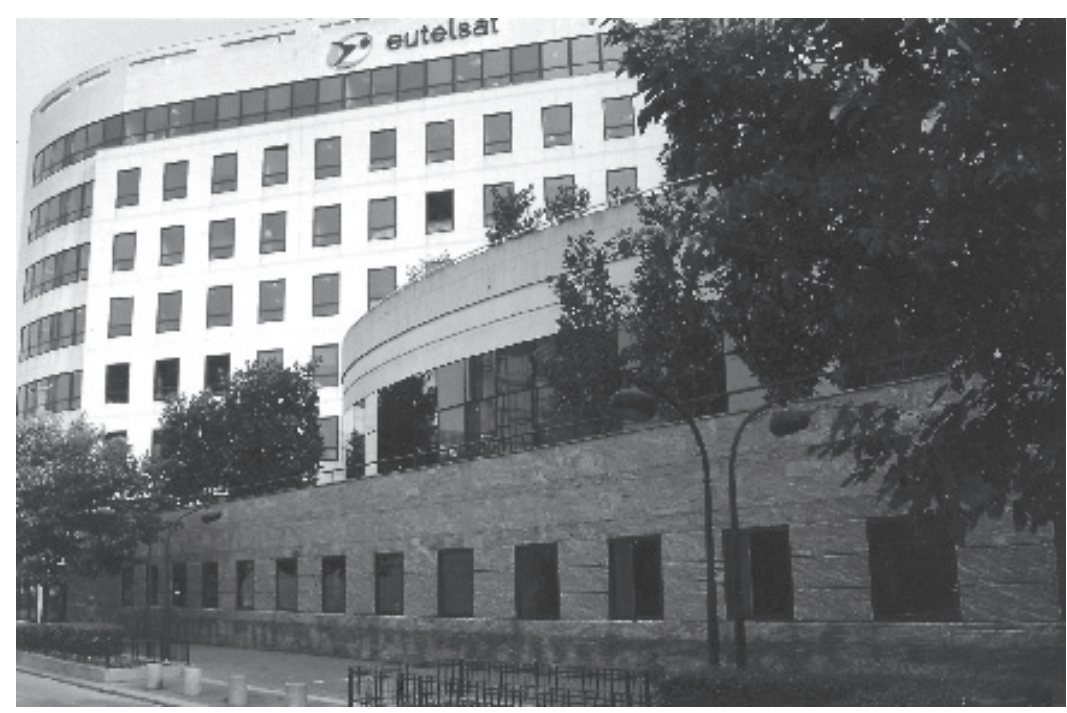

Foto 7 
Tratava-se da conciliação de um discurso "urbanístico" e de um discurso "cênico", ao mesmo tempo complementares e em oposição. $\bigcirc$ primeiro - o "formalismo urbanístico" de Provost - insistia sobre a estruturação do espaço urbano pelos jardins, o segundo sublinhava a "cenarização" dos jardins por meio da "narrativa vegetal" de Clément (DEBIÉ, 1992). Esse casamento de linguagens, imposto pela prefeitura de Paris, deveu-se não tanto às analogias de forma dos dois projetos (grande gramado central - Foto 8, "enquadrado" por rampas e canais de água, bem como por jardins temáticos), mas, sobretudo, à legitimação recíproca dos dois programas, ambos baseados em um "lirismo neo-romântico eficaz" (GARCIAS, 1993, p. 111).
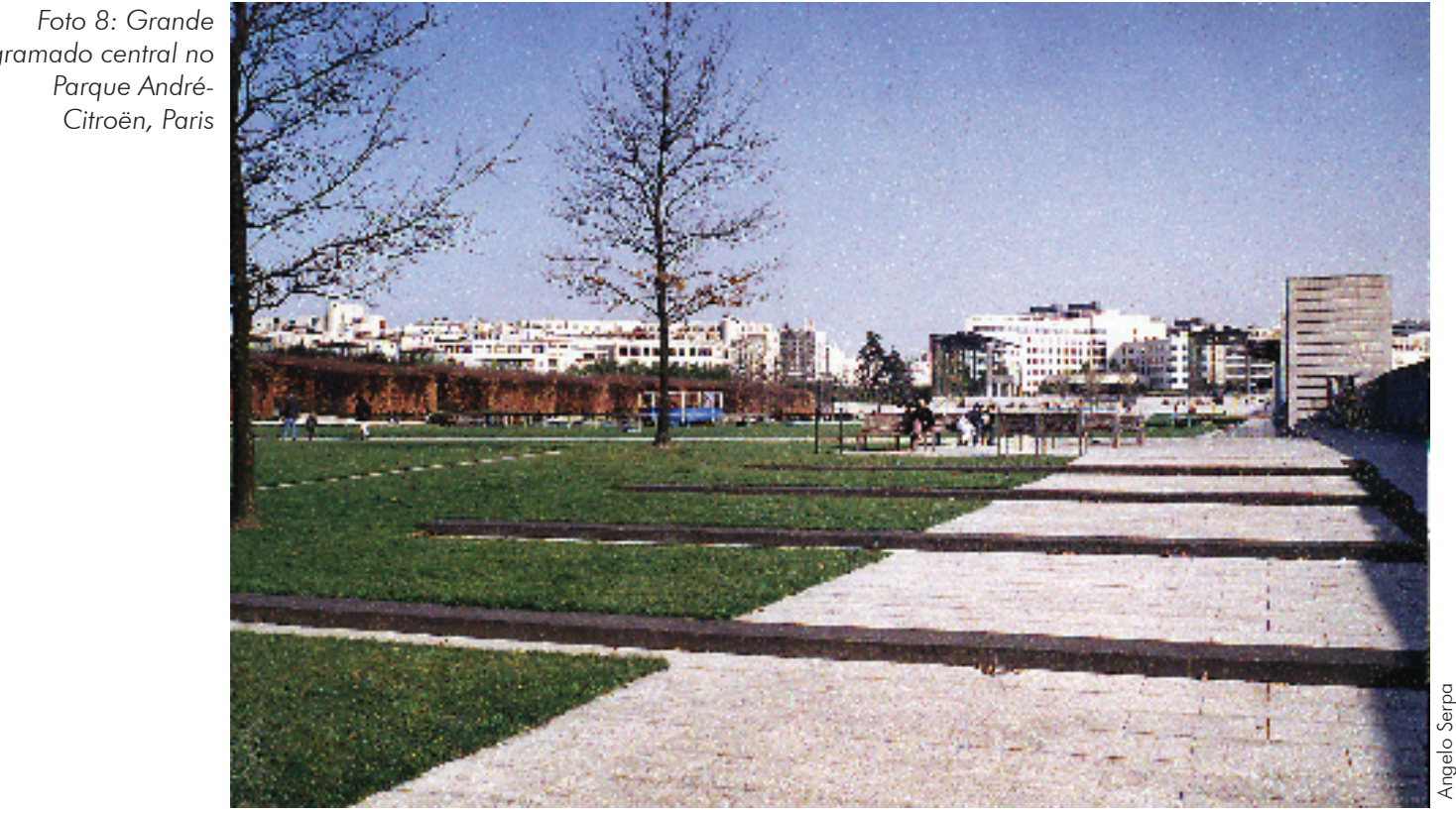

Para a prefeitura de Paris, um parque dessa importância deveria apoiar-se em uma "idéia forte", associando o "rigor" de Provost aos conhecimentos botânicos de Clément ("Un parc pour le XXlème siècle", Paysages et Actualités, 1992). Com o Parque André-Citroën, a prefeitura de Paris pretendia "rivalizar" com o governo central francês e "seu" Parque de La Villette. $\bigcirc$ objetivo era o de apontar um novo modelo para o "Parque do Século XXI", abandonando a visão arquitetônica e o espírito de "instalação artística" do Parque de Tschumi. Uma década mais tarde, tratava-se de conceber e implantar, em Javel-Citroën, "um parque de paisagistas", onde os jardins de Clément deveriam desempenhar um papel central.

O parque é atravessado em diagonal por um caminho que liga as partes norte e sul. No centro, um vasto gramado é rodeado por belvederes revestidos de granito negro e por rampas (Foto 9), fontes e canais de água. Duas grandes estufas de 15 metros de altura - batizadas de "pomar" e de "estufa mediterrânea" - determinam a perspectiva visual a partir da direção sudeste (Foto 10). Uma esplanada de jatos de água com altura variável foi instalada entre 


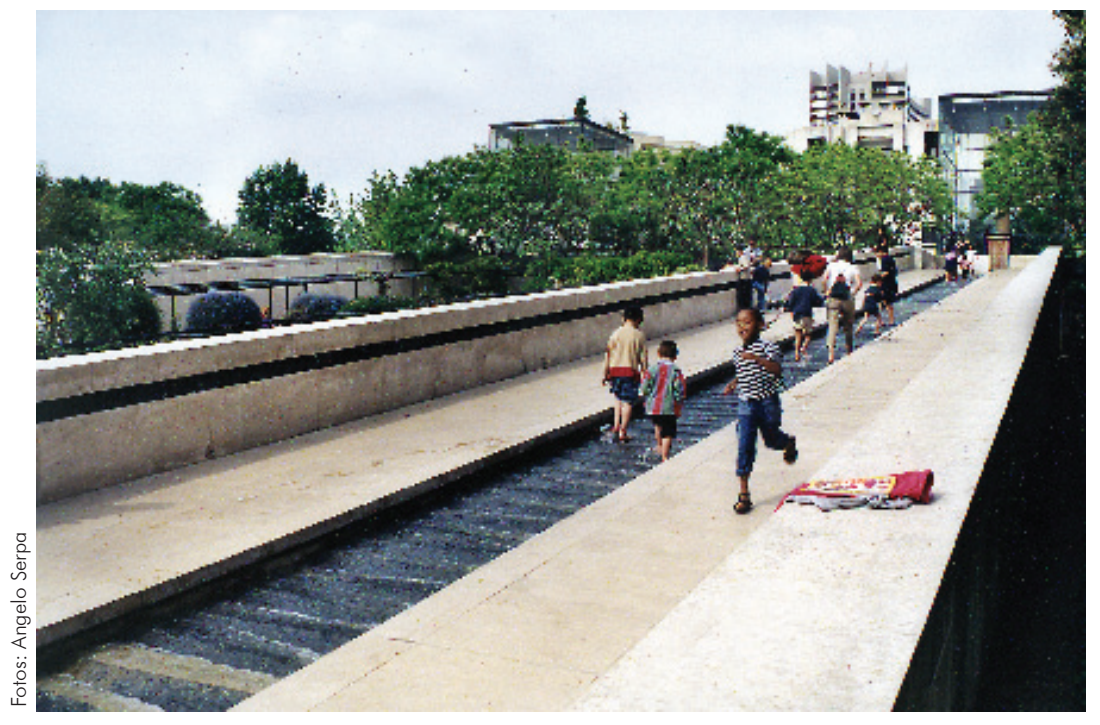

Foto 9: Rampas de água com detalhe das pequenas estufas ao fundo, Parque André-Citroën

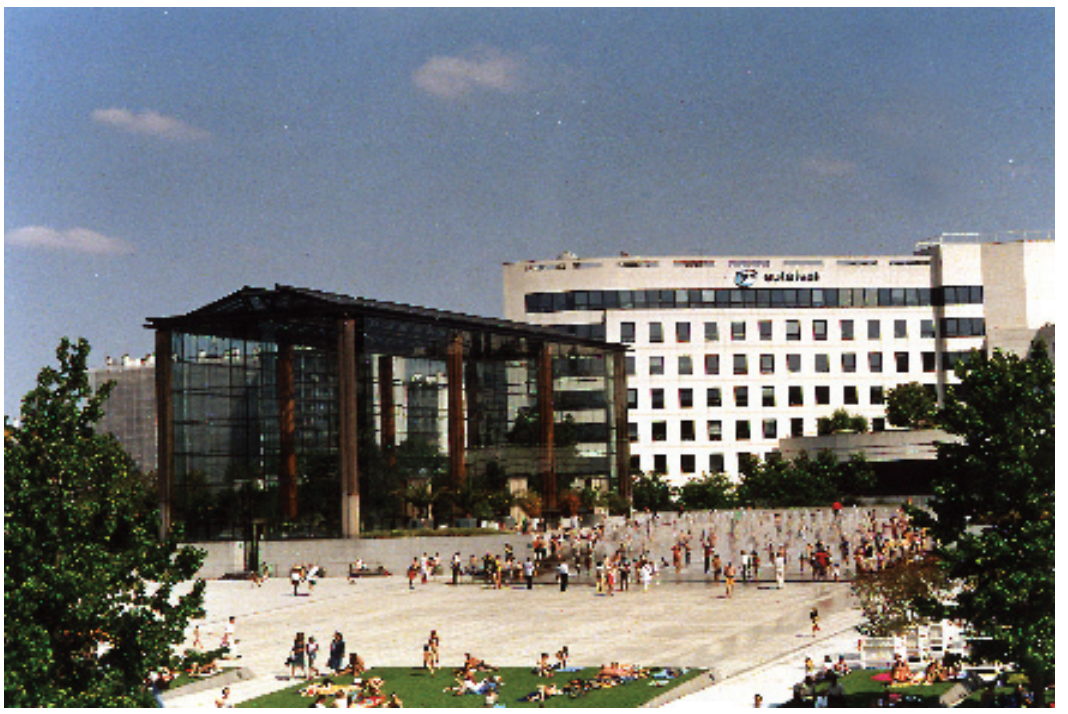

Foto 10: Estufas de 15 metros de altura determinam a perspectiva visual, a partir da direção sudeste, Parque André-Citroën

Foto 17: Esplanada de

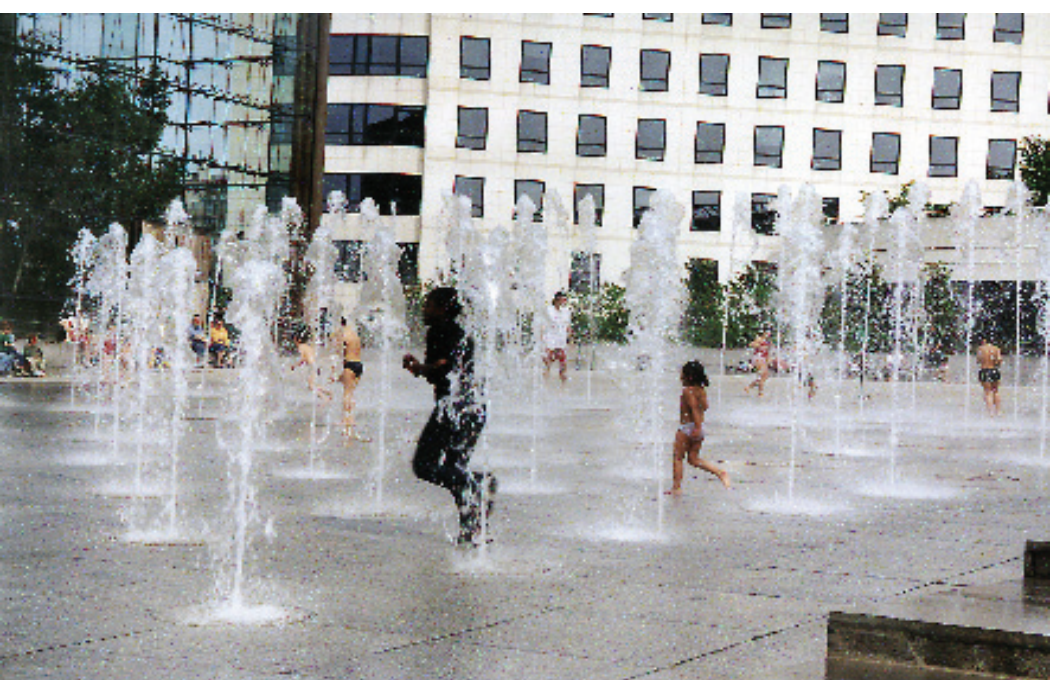
jatos de água com altura variável, instalada entre as duas estufas, Parque AndréCitroën 


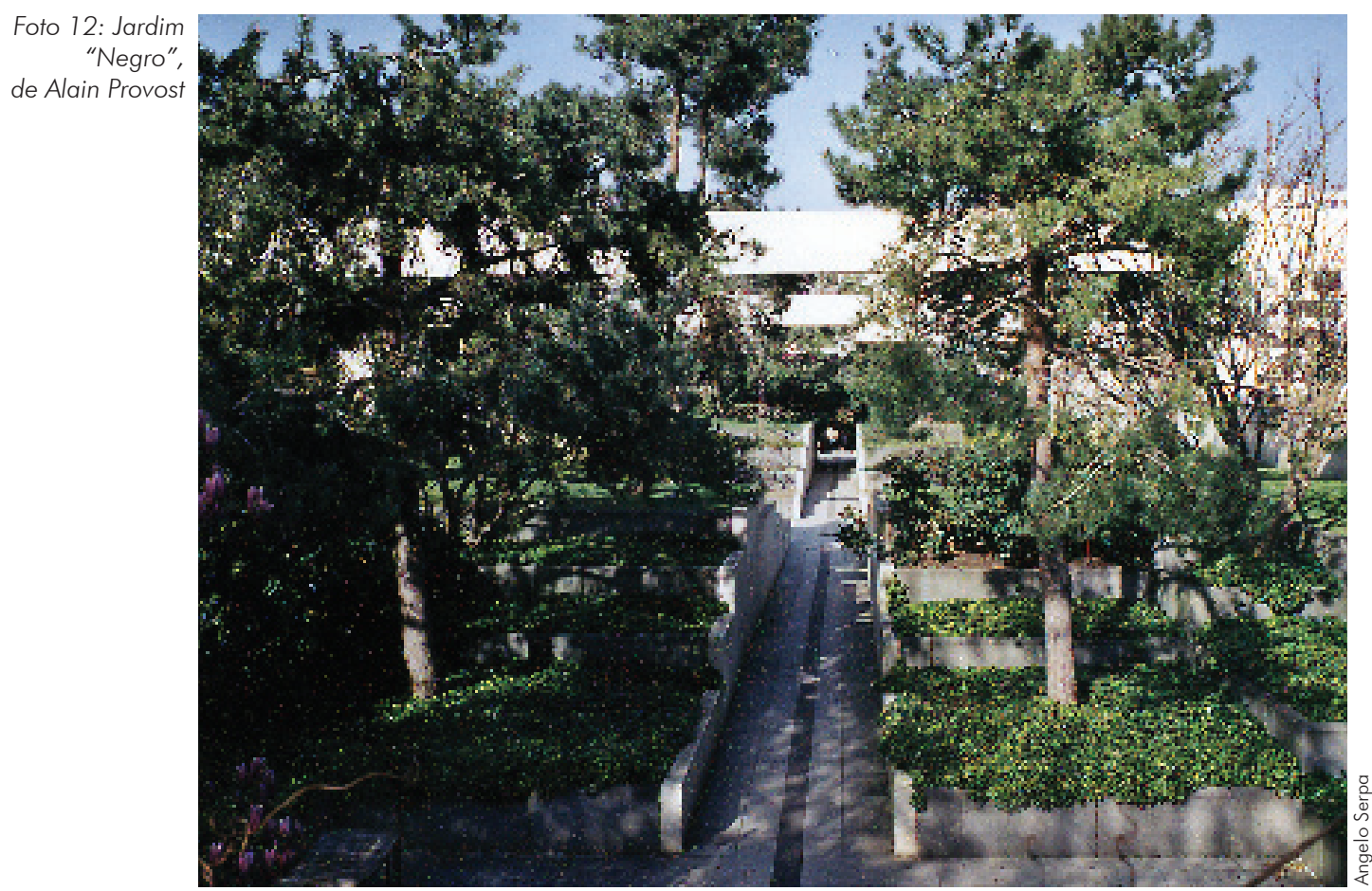

as duas estufas (Foto 11). Os jardins temáticos e mais seis estufas menores se localizam também em volta do espaço gramado central: ao norte, o "Jardim do Movimento" - no qual os jardineiros aprendem uma nova maneira de lidar com as "ervas daninhas" (RACINE, 1999, p. 202), ao sul, os jardins "Negro" (Foto 12) e "Branco", de Provost, e, na direção nordeste, os seis jardins seriais de Clément, instalados entre as rampas de água: os jardins azul, verde, laranja, vermelho, dourado e prateado.

Parque e bairro estão perfeitamente articulados, o que demonstra um desejo claro de "simbiose" entre os ambientes vegetados e construídos, pela ausência de grades e muros em quase todos os imóveis residenciais e comerciais (RUEFF, 1993); não há ruptura visual entre as árvores do parque e as ruas do bairro. Um dos objetivos principais da operação urbanística era justamente o de obter essa permeabilidade visual, graças à prescrição de abertura da massa construída sobre os espaços plantados do parque; o de promover uma unidade na composição plástica das fachadas fronteiriças ao parque, insistindo sobre um tratamento arquitetônico do conjunto a partir do parque, e irradiando por toda a periferia do bairro (MILLIEX, 1993). As "vilas" desenhadas por Roland Simounet (Fotos 13, 14 e 15) exprimem esse desejo de abertura sobre o parque, fazendo dialogar os edifícios com os jardins seriais de Gilles Clément: "a cada vila privada corresponde uma pequena estufa do jardim serial; reciprocamente, cada fachada se projeta entre duas estufas, sobre o jardim serial respectivo, para o qual ela funciona como o fundo da cena" (MILLIEX, op. cit., p. 94). 


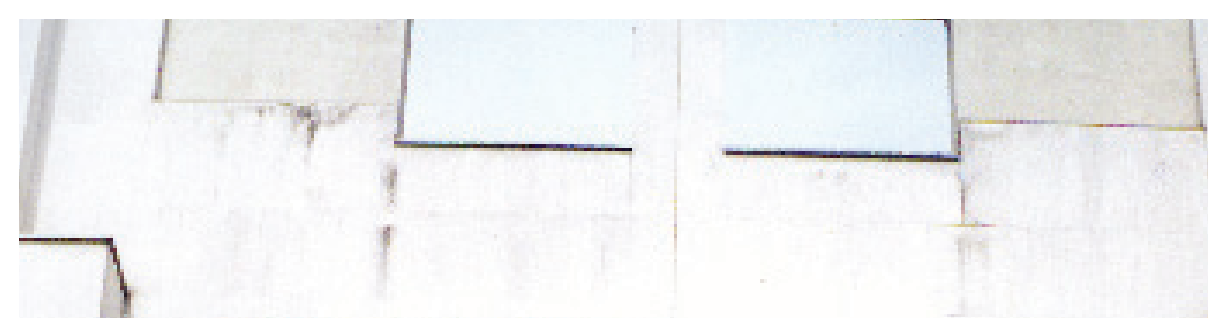

Fotos 13,14

15: As "vilas"

desenhadas por

Roland Simounet

exprimem o desejo

de abertura sobre o

parque

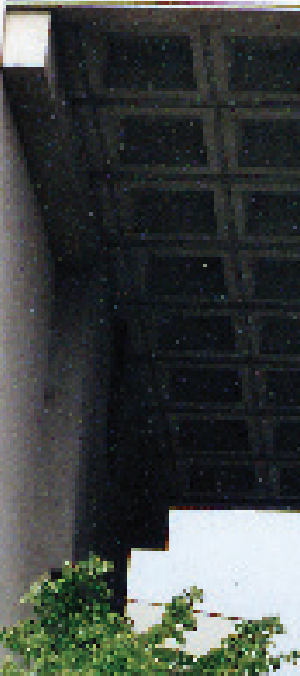

ba

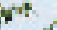

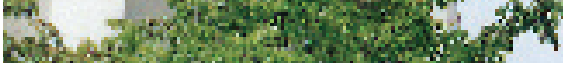

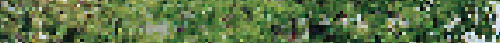

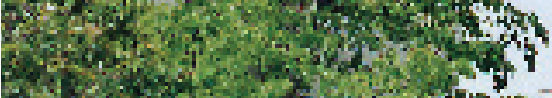

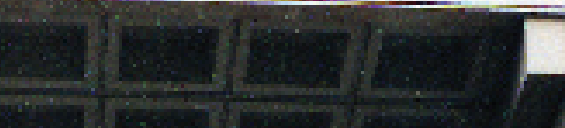

sistorin

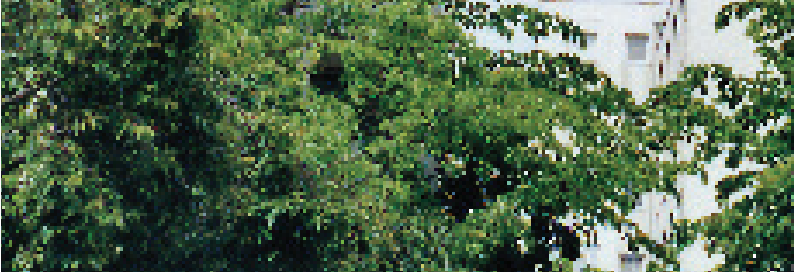

,

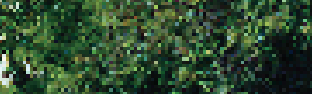

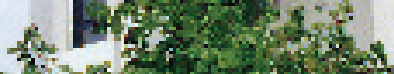

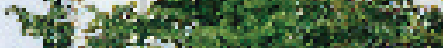
Whe $y^{2}$. Hor. 20.
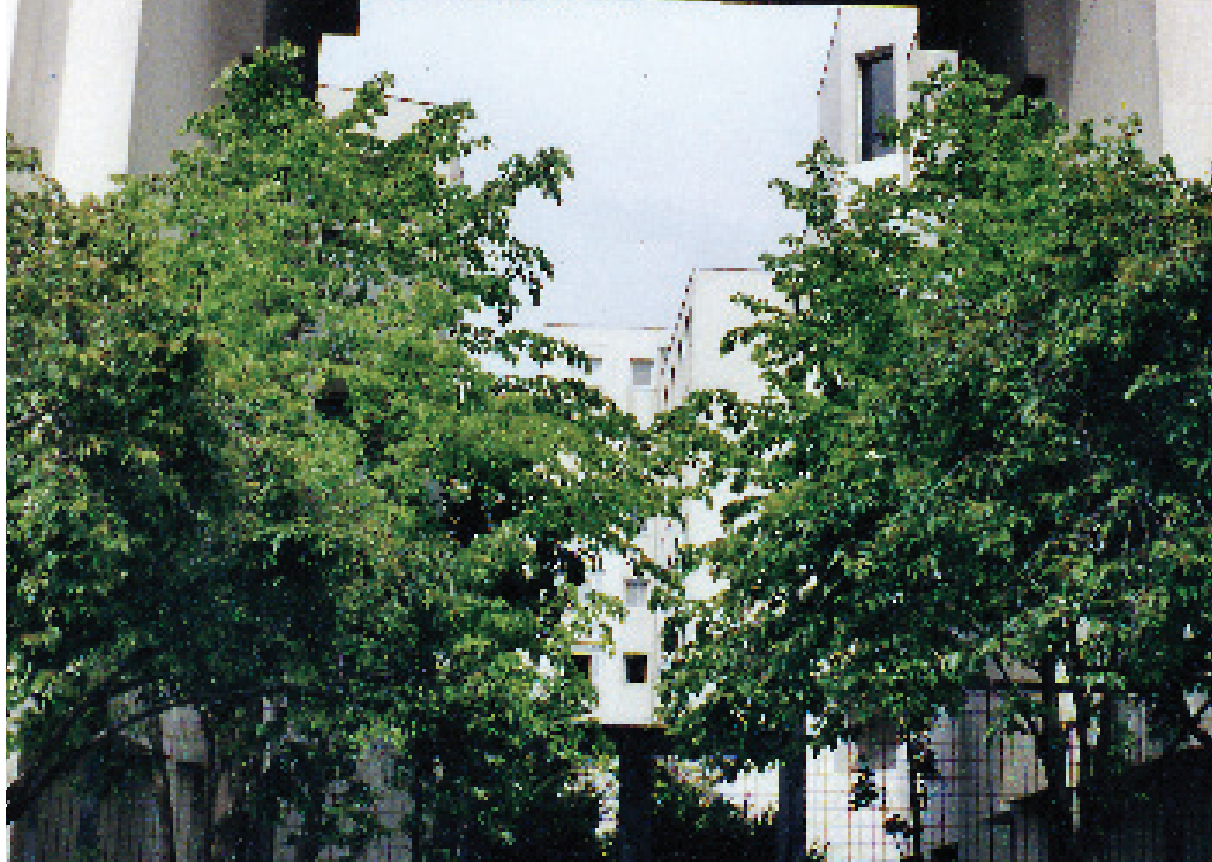

sains
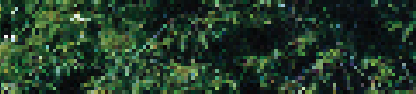

er.ant
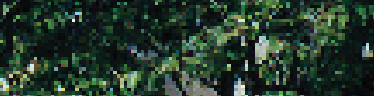
3.

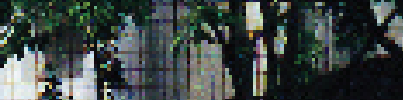

i *is
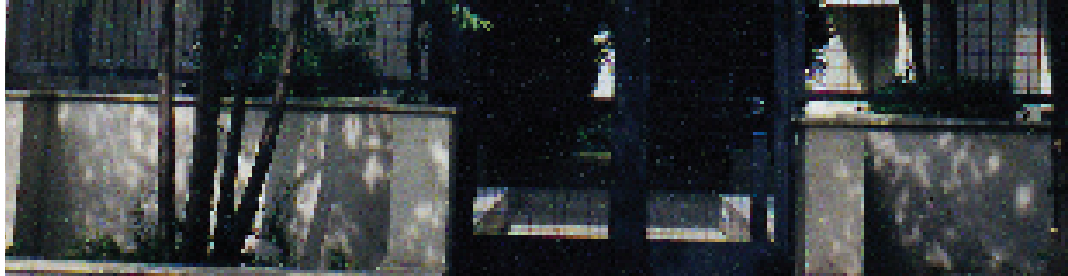

hos
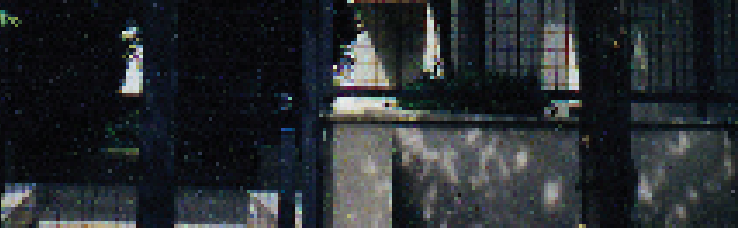

stiv

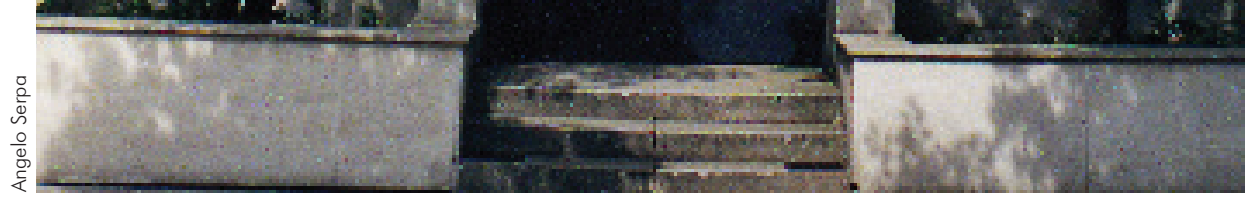



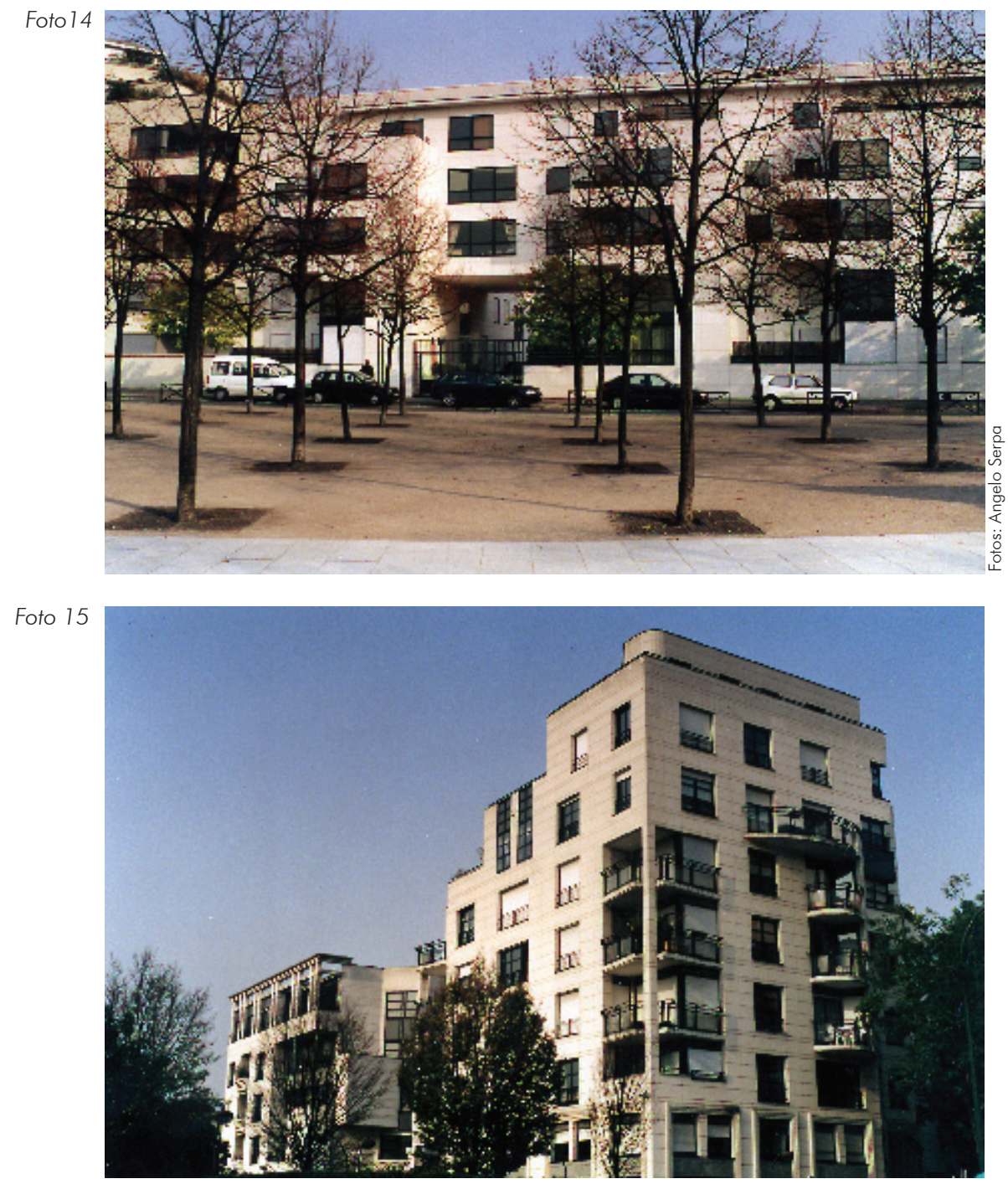

Foto 16: Jardim do Movimento de Gilles

Clément, Parque André-Citroën

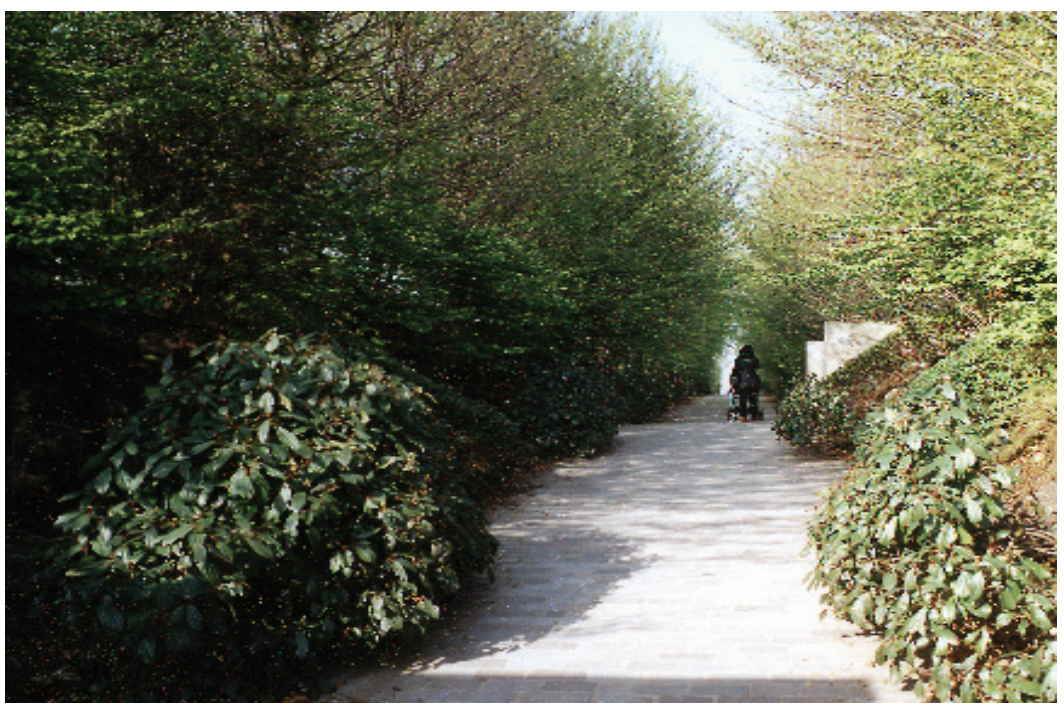




\section{Os Jardins de Gilles Clément}

Como mencionado anteriormente, trabalha-se aqui pensando-se em duas escalas: uma que corresponde a uma dimensão de utilização pelos habitantes de uma grande cidade, e outra relacionada com usuários de bairros próximos que desejam espaços "mais íntimos" (CLÉMENT, 1993, Un jardin du XXème siècle à Paris, Dialogue dans le Parc André Citroën). Visto assim, as grandes linhas de concepção do espaço correspondem melhor ao registro da monumentalidade de um parque à altura de uma grande cidade como Paris, para que ele não se torne um simples jardim de vizinhança (VIGUIER, 1993, Un jardin du XXème siècle à Paris, Dialogue dans le Parc André Citroën). Em conseqüência, modificam-se as relações entre os elementos vegetais e os construídos, e o jardim se transforma em um subespaço no interior de um grande parque, um elemento "natural" entre elementos "artificiais". $O$ jardim se transmuta em "museu do vegetal", devendo fornecer ao público uma quantidade específica de informações relativas às espécies vegetais e suas origens ou simbolizar os ciclos naturais, como no Jardim do Movimento (Foto 16), no Parque André-Citroën (INGALINA, 1997; DEBIÉ, 1992).

Os jardins foram concebidos como espaços pedagógicos, como uma espécie de museu a céu aberto, no qual os usuários e visitantes são induzidos a percorrer um itinerário que vai de jardim em jardim, o que parece restringir outros usos e práticas. Apesar da presença de (poucas) pessoas tranqüilamente deitadas em bancos nos jardins seriais de Clément, a concepção de espaços vegetados temáticos como "cenários naturais", que não podem ser utilizados "livremente", acaba por determinar as atitudes dos usuários. A maior parte deles assume uma postura contemplativa em relação a esses espaços, com uma única motivação implícita, de "aprender com a natureza".

Os jardins seriais são, segundo seu criador, para serem "lidos" pelas correspondências e associações simples e banais. Para cada um deles estão associadas, além de uma cor dominante, uma escolha específica de materiais e uma relação com um dos cinco sentidos. Também para cada jardim há sempre um metal associado, assim como um planeta e um dia específico da semana. Cada um dos seis jardins seriais, assim como o Jardim do Movimento, induzem a uma relação simbólica específica com a água, elemento determinante na concepção do parque. Assim, o Jardim do Movimento representa a fonte original; o Jardim Azul (Foto 17), a gota de água (que cai de uma pérgula sobre uma pedra azulada); o Jardim Verde (Foto 18) é aquele da pequena fonte; o Jardim Laranja evoca um pequeno riacho; o vermelho, a cascata, e o prateado (Foto 19), com seus deks de madeira, representa o rio que vai ao encontro do mar (CLÉMENT, 1999).

O Jardim do Movimento deve "aceitar" e incorporar, gradualmente, todos os vegetais espontâneos compatíveis com o meio. É formado de plantas outrora consideradas como "daninhas". É o jardim das metamorfoses "radicais", das 
transformações "brutais" de aspecto. Sua estruturação é fluída (principalmente por meio do plantio de "cortinas" de bambus) e sua implantação é originada, sobretudo, do plantio inicial de herbáceas, realizado em setembro de 1991. $\bigcirc$ movimento também está contido, como princípio criador, nos jardins seriais: é um movimento "atômico", seguindo a lógica das transmutações dos corpos elementares descritos pela alquimia (transformação de um elemento em outro por um salto energético; assim, o chumbo pode transformar-se em ouro para os alquimistas) (CLÉMENT, 1999).

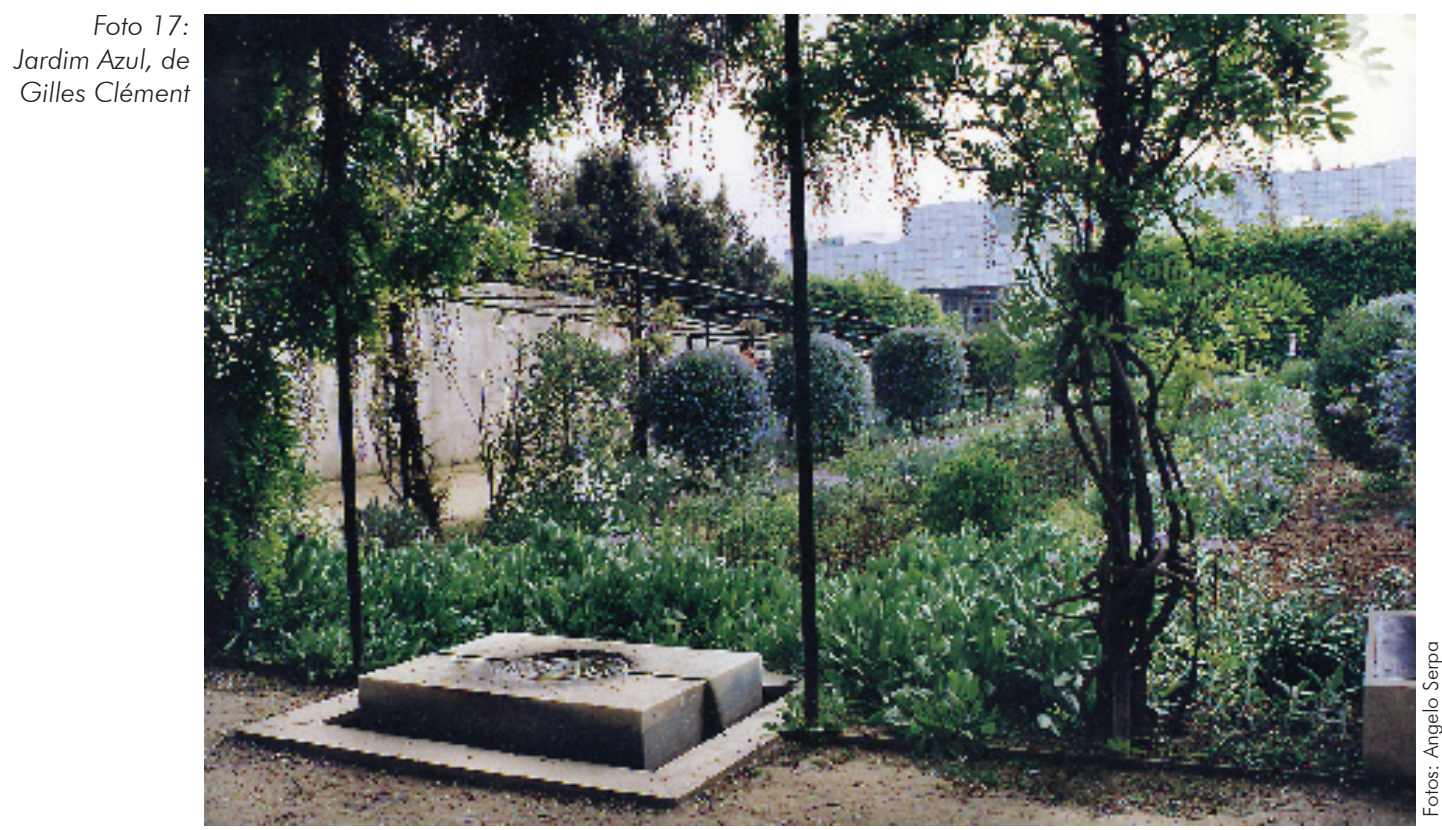

Foto 18: Jardim Verde, de Gilles Clément

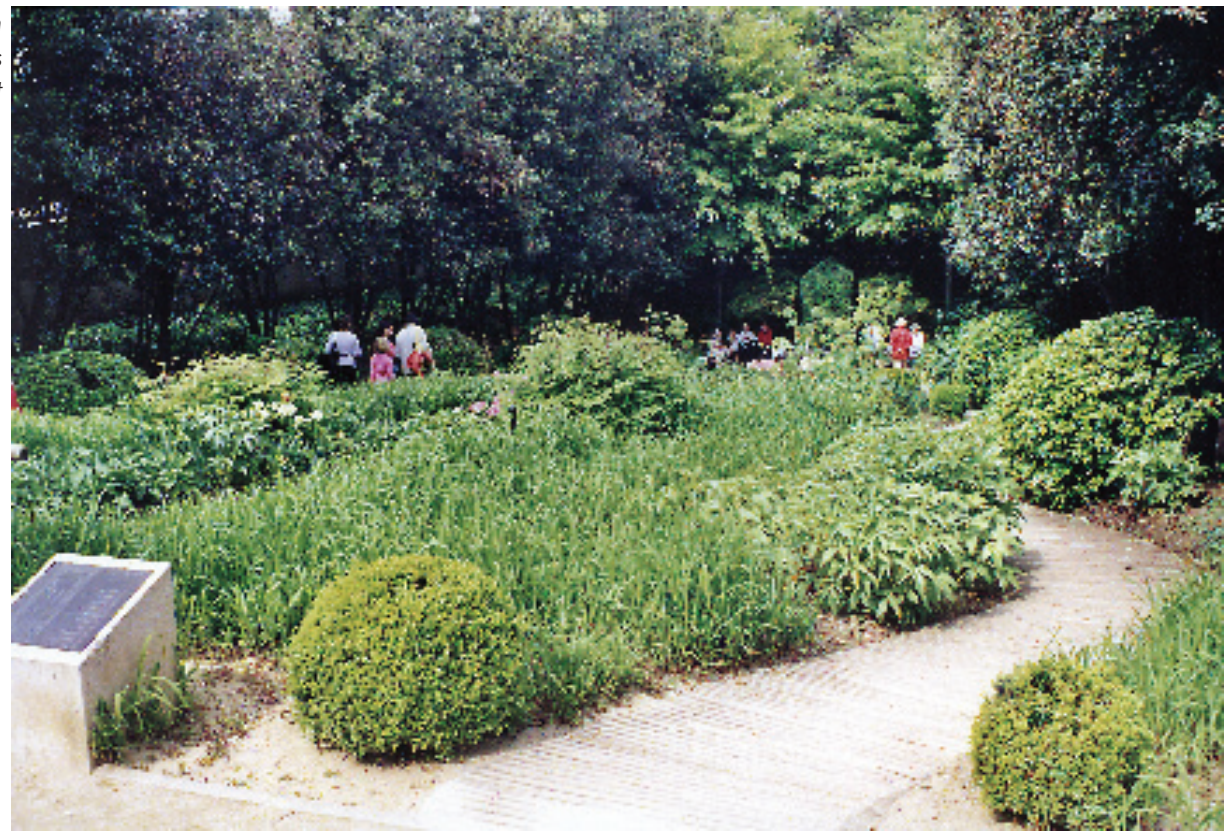




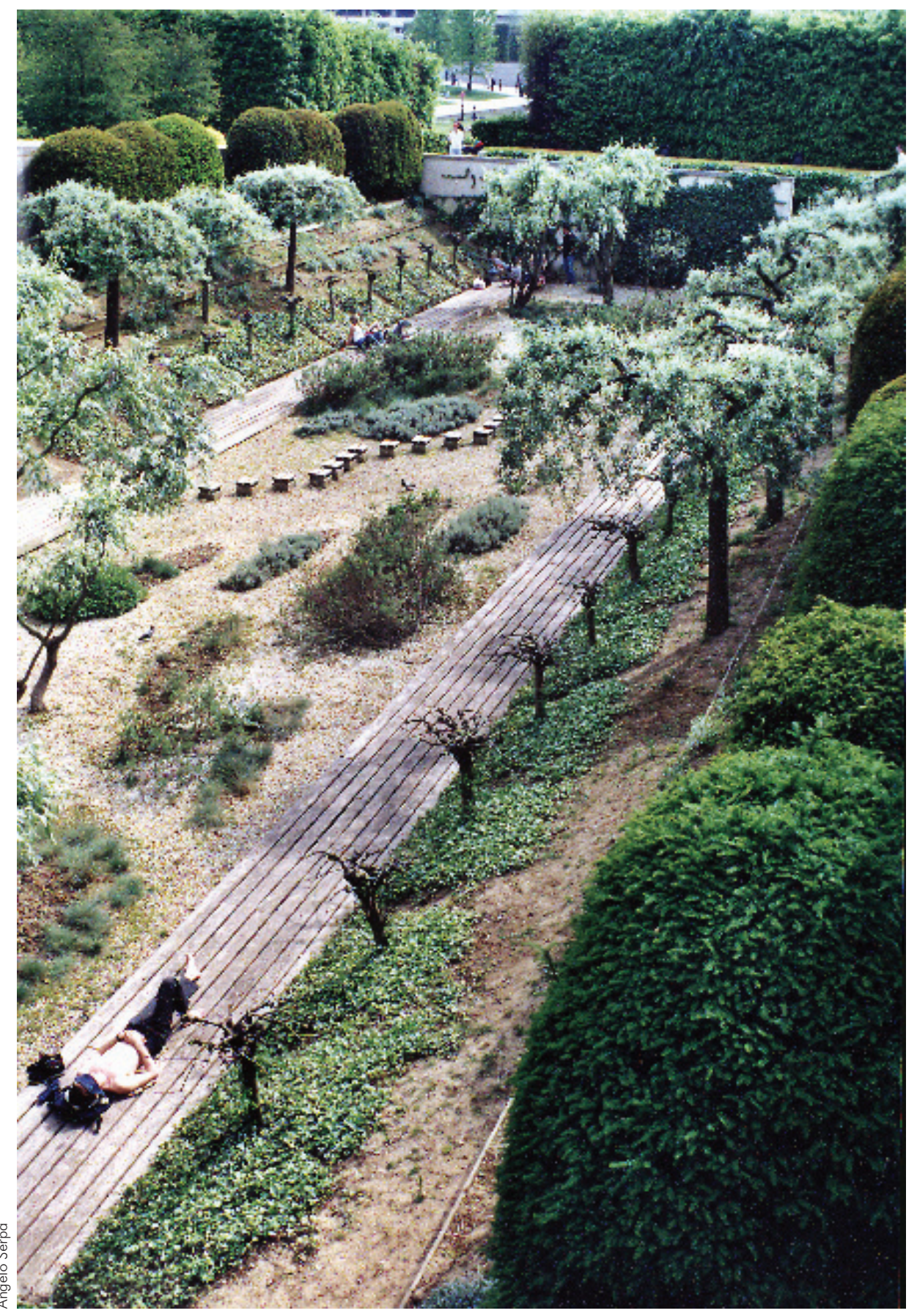

Foto 19: Jardim Prateado, de Gilles Clément

\section{O Outro Lado da Moeda: Segregação Socioespacial}

152 Marcados por uma história, pela expressão de estilos e de modismos, os parques públicos sempre representam e expressam valores éticos e estéticos, que ultrapassam largamente seus limites espaciais. Seja qual for a época, esses valores estão sempre presentes no discurso oficial e nas políticas públicas 
aplicadas às cidades: higienismo, pacifismo, beleza estética. Essa reunião de valores reforça uma metáfora que o parque público é um instrumento de integração social e espacial das cidades. $\bigcirc$ confronto entre o discurso oficial relativo à implantação de grandes parques públicos e a política habitacional aplicada em Paris contradiz frontalmente essa idéia.

Com 190.000 unidades habitacionais de um total de 1,3 milhões, o parque residencial de caráter social (unidades "HLM", com aluguéis subsidiados com recursos públicos) em Paris representa 15\% do total de habitações na cidade. Mas seu peso na construção de novas residências nos últimos anos é muito maior, já que ele constitui cerca de 30\% do patrimônio construído depois da Segunda Guerra Mundial. Porém, a distribuição dessas "habitações sociais" é muito desigual nos distritos parisienses: inexistem no 7o e no 8o e representam uma em cada três unidades habitacionais no $12 \circ$ e no 13 distritos. Elas também estão concentradas na mão de poucos proprietários, três sociedades de economia mista com a participação da prefeitura de Paris, que detêm $71 \%$ do patrimônio construído (LACOSTE, 2000).

Se, antes da Segunda Guerra, Paris concentrava a maior parte da construção social, hoje isso se tornou um affaire da periferia, isto é, dos municípios que compõem a região metropolitana parisiense. Em 1950, a cidade concentrava $60 \%$ do parque residencial de caráter social; hoje esse porcentual é de menos de 18\%! (LACOSTE, op. cit.). O Escritório Público do Parque Residencial "HLM", totalmente regido pela prefeitura de Paris, administrava, em 1982, 2.517 unidades habitacionais em Hauts-de-Seine; 4.369, em Seine-SaintDenis; e 4.443, em Val-de-Marne. A Direção Imobiliária da Cidade de Paris, um organismo de economia mista, no qual a prefeitura de Paris controla 37\% do capital, geria, naquele mesmo ano, 1.035 apartamentos em Seine-SaintDenis; 1.542, em Val-de-Marne; 807, em Essonne; e 224, em Hauts-de-Seine. Finalmente, a Sociedade Anônima de Gestão Imobiliária, na qual a prefeitura de Paris detém 40\% do capital, administrava 835 apartamentos em VilleneuveSaint-Georges; 391, em Saint-Denis; 288, em Sevran; e 1.447, em Créteil (BELMESSOUS, 2000).

$\bigcirc$ processo de construção de novos bairros, como Javel-Citroën e Bercy, acaba por expulsar parte de seus antigos habitantes, tornando os municípios da região metropolitana de Paris verdadeiros "receptáculos da população mais pobre do município-sede" (BELMESSOUS, op. cit., p. 81). $\bigcirc$ insignificante número de habitações sociais construídos em Paris nos últimos anos, ante a demanda sempre crescente por esse tipo de habitação, torna proibitivo para os menos favorecidos a permanência na cidade. Uma análise do porcentual de habitações sociais (PLA) - em relação ao total do patrimônio construído - nas zonas de planejamento (ZACs), em que foram implantados os novos parques públicos, confirmam essa tese: em Bercy, 45\%; em Javel-Citroën, 32\%; no Bassin de La Villette, 36\%; e, no setor Villette Sud, 34\%. 
Trabalhando com os dados do censo de 1999, o Ateliê Parisiense de Urbanismo elaborou uma carta para Paris e sua região metropolitana, com a estrutura socioprofissional simplificada da população ativa. Analisando-se esses dados, pode-se afirmar que tanto no bairro de Bercy como no bairro de Javel-Citroën, há uma predominância de profissionais liberais, administradores de empresas e trabalhadores com nível elevado de estudos. Isso é mais evidente em Javel-Citroën, em que este tipo de população corresponde a mais de $50 \%$ dos habitantes do bairro, enquanto, em Bercy, o porcentual varia entre 40 e mais de $50 \%$.

O paisagista Gilles Clément ${ }^{3}$, um dos conceptores do Parque André-Citroën, em entrevista concedida no âmbito de uma pesquisa de pós-doutorado, realizada no Laboratório Espaço e Cultura da Universidade de Paris IV, acredita que a prefeitura de Paris, baseada em um discurso contraditório, conduz uma política estranha de requalificação do espaço urbano, "porque, por um lado, cria novos parques, que são realmente interessantes em termos de concepção, mas, por outro lado, expulsa para a periferia os antigos habitantes dos bairros onde esses parques são implantados. Essas pessoas não possuem renda para continuar em Paris, por isso são rejeitadas pela cidade". Para Clément, o discurso oficial é contraditório, porque defende a idéia que o parque proporcionará aos habitantes da cidade uma "vida mais agradável", mas, na verdade, esses parques são, em sua maior parte, reservados a um tipo específico de público, que não inclui os menos favorecidos, em termos de renda e formação. Leia, a seguir, os trechos principais da entrevista:

\section{"Qual o papel e quais funçóes deve desempenhar o espaço público na cidade contemporânea?}

Eu só posso falar a partir da minha experiência prática. Eu não me considero um 'teórico' do espaço público. Eu penso que atualmente há duas formas possíveis para que o espaço público possa existir. A primeira, a partir da evolução progressiva do tecido urbano, que cria 'brechas' para a implantação de um parque, uma praça, um jardim, qualquer coisa de não construído, em lugares onde antes havia fábricas ou edifícios. No caso de bairros muito densos, esses espaços cumprem uma determinada função, por razões de proporção de metro quadrado de áreas verdes por habitante, por exemplo. E a cidade aproveita a oportunidade para criar ali um parque. É o caso do Parque André-Citroën, implantado em um bairro totalmente construído, de perfil industrial. Alguns edifícios

(3) Gilles Clément é engenheiro agrônomo, "jardineiro paisagista", como ele próprio se define, botânico e entomologista. Concebeu e implantou numerosos jardins, entre os quais o Jardim do Movimento do Parque André-Citroën, os jardins de Rayol, da abadia de Valloire, do Castelo de Blois e dos arcos de La Défense. É autor de numerosos ensaios e romances. 
e os prédios das fábricas foram demolidos, dando oportunidade para a construção de um parque de 14 hectares. Neste caso, é a 'subtração' de edifícios do espaço urbano que vai dar origem a um parque. Mas há jardins e parques na história de Paris e de outras cidades que determinaram o surgimento de um outro tipo de urbanismo, como no caso do Jardin de Tulleries. Quando Le Notre concebeu e implantou este parque, ele abriu uma nova perspectiva sobre os Champs-Élysées, ele foi o precursor de uma nova espécie de urbanismo, baseado em perspectivas axiais.

Fotos 20 e $21:$

Capoeira no Parque André-Citroen, Paris

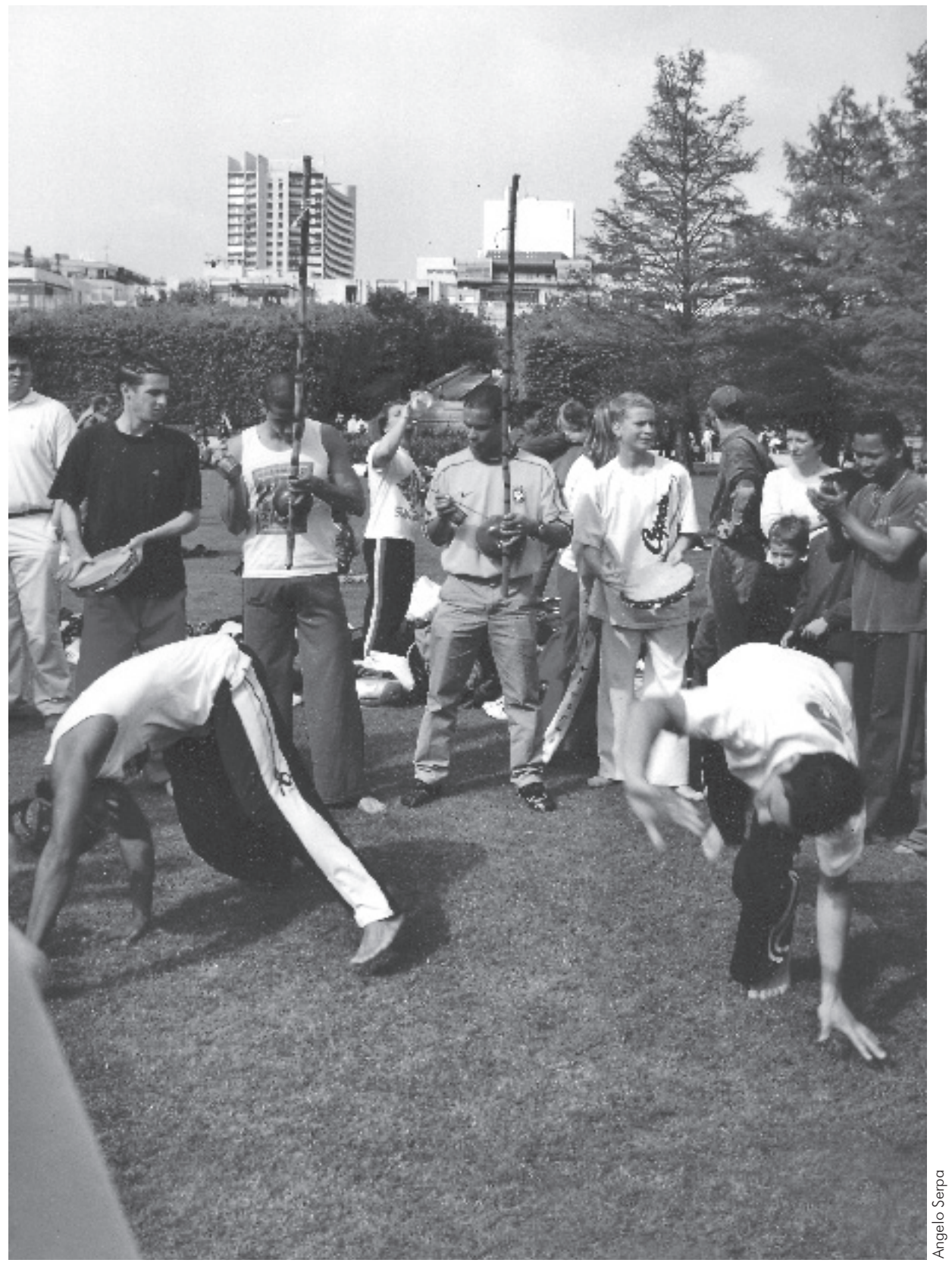


Por que um parque? O senhor vê semelhanças da política atual com a implantação de parques pela ação de Haussmann, no século XIX? Eram também operações baseadas na subtração?

Evidente. Nessa época, o discurso político de Haussmann e Alphand era de cunho higienista. A ida a um parque estava associada a questões de saúde, ia-se a um espaço assim para respirar o bom ar dos jardins. Por isso, houve uma multiplicação de parques e pequenas praças na Paris do século XIX. Hoje, a política de implantação de espaços vegetados da Prefeitura de Paris não é muito diferente disso. Não é exatamente o discurso higienista do século XIX, hoje o discurso é frio e matemático, enfatiza uma quantidade mínima de metros quadrados de áreas verdes por habitante. Mas essa política é estranha, porque, por um lado, cria novos parques, que são realmente interessantes em termos de concepção, mas, por outro lado, expulsa para a periferia os antigos habitantes dos bairros onde esses parques são implantados. Essas pessoas não possuem renda para continuar em Paris, por isso são rejeitadas pela cidade. O discurso oficial é contraditório, porque defende a idéia de que o parque dará aos habitantes da cidade uma vida mais agradável, mas, na verdade, esses parques são, na sua maior parte, reservados a um tipo específico de público, que não inclui os menos favorecidos, em termos de renda e formação.

\section{O senhor concorda que esses parques deveriam atender a toda a população da aglomeração parisiense?}

Sim, pois são parques suficientemente grandes. O Parque AndréCitroën é o menor dos três recentemente implantados, mas grande o suficiente para atingir um público maior. Portanto é correto supor que além dos habitantes dos bairros próximos, pessoas de bairros mais distantes também utilizem o parque. Há também aqueles que vêm até de outras cidades e países. Simplesmente porque o parque tornou-se conhecido. Sem falar em um público específico de escolas, um pouco menos atualmente, mas logo depois da inauguração do parque havia muitos alunos de escolas.

Pesquisando in loco os usos do parque, descobri que ele funciona também como lugar de encontro para praticantes de capoeira...

Isso é muito bom, algo inteiramente imprevisível. Quando concebemos um espaço público deste gênero, nós não sabemos o que vai acontecer. Há a expectativa que ele favoreça diferents usos, mas não sabemos exatamente quais. Por que a prática de capoeira 


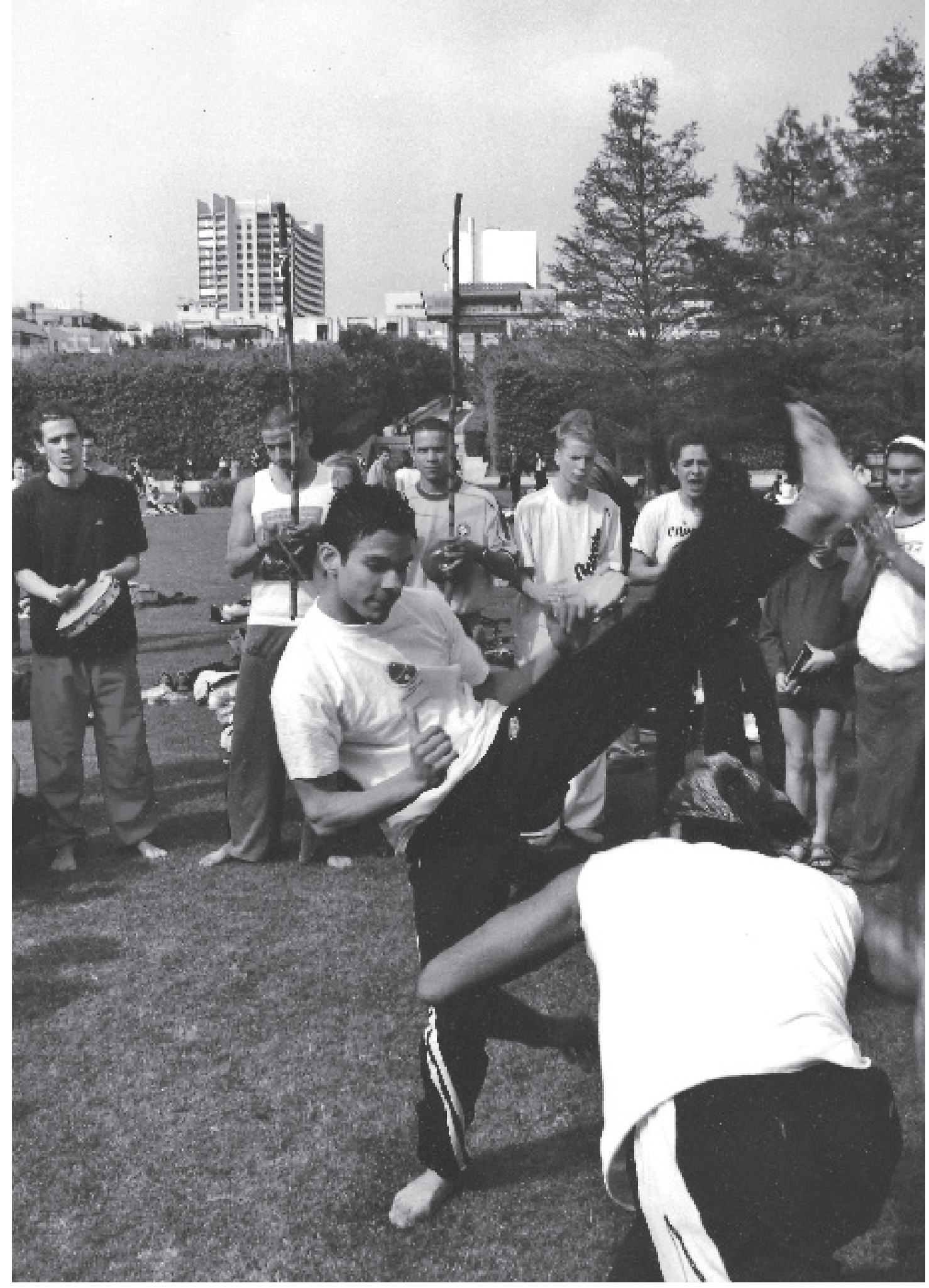


no parque? Talvez por causa do grande gramado central. Eu me lembro de ter visto pessoas ensaiando peças de teatro nos jardins, outros que tocavam percussão perto dos bambus do Jardim do Movimento. Há espaços fechados, outros abertos, que permitem uma gama variada de usos possíveis.

\section{A freqüentação intensa prejudica/prejudicou a evolução do Jardim do Movimento?}

Digamos que nós não previmos a quantidade de pessoas que vieram conhecer os jardins nos primeiros dias de funcionamento do parque, entre 10 e 11 mil pessoas no primeiro final de semana, segundo a Prefeitura de Paris. Foi uma coisa imprevista, isso demonstrou a fragilidade de alguns espaços, mas não houve vandalismo nem degradações importantes.

\section{Ao contrário do Parque de La Villette, onde isso ocorre...}

Porque é um parque que abre à noite, o que amplia a quantidade de usuários e complica a fiscalização.

\section{O senhor é contrário à possibilidade de utilizar um parque como o André-Citroën também no período noturno?}

É uma pena a restrição de horário, mas, por outro lado, é uma forma de melhor proteger os jardins. O Parque André-Citroën apresenta espaços muito frágeis e sofisticados em termos de diversidade vegetal e concepção. Um parque assim pode tornar-se ponto de venda de drogas no período noturno, por exemplo. No Parque de La Villette há um sistema de segurança que funciona bem, mas é dispendioso.

Um lugar acessível a todos, em qualquer horário, não deveria ser uma das características principais de um espaço público?

Eu não posso responder, se não for a partir da minha experiência. Ora, eu sou antes de tudo um latino, antes de qualquer coisa favorável à Agora, antes de tudo interessado na observação e no olhar sem velocidade do caminhar a pé. Eu não entendo o espaço desenhado para o automóvel, para os estacionamentos... Para mim, o espaço público utilizável é aquele que pode ser usado na escala humana, um pouco como o espaço romano. Portanto, ele não é absolutamente compatível com a vida que levamos atualmente. Hoje condenamos ao isolamento bairros inteiros para estabelecer novas áreas de pedestres, mais isso acaba complicando ainda mais as coisas, pois não podemos segregar um bairro dessa forma. Eu penso que um espaço desenhado para os automóveis 
não é utilizável. Na maior parte do tempo isso vem acompanhado de passarelas e de passagens subterrâneas para que se possa atravessar as vias rápidas, cada vez mais numerosas. Não há passeios ou, quando eles existem, são muito estreitos. Andar a pé tornou-se algo perigoso. Na maior parte dos casos, aquilo que chamamos de espaço público não pode ser chamado assim. São espaços mecânicos, feitos para robôs e máquinas, não para os seres humanos. Vamos para um espaço público para se sentar tranqüilamente, para ver e ser visto, para encontrar pessoas. Não se pode encontrar alguém se sua vida é posta em risco...

\section{O senhor afirmou uma vez que todos os jardins são políticos...}

Os jardins são políticos na medida em que eles são uma expressão acabada do pensamento vigente em uma época específica. Falo dos jardins históricos, dos jardins importantes sob esse ponto de vista. Talvez eu tenha ido um pouco longe demais dizendo que todos os jardins são políticos. Os jardins importantes são políticos, mas isso é também resultado de uma política que exprime o pensamento filosófico, as crenças de um determinado momento histórico. Ao mesmo tempo, eles resultam também de um modo de gestão, de uma idéia de poder. Não necessariamente uma visão de poder como em Versalles. Hoje, com a ecologia, o homem percebe-se como parte integrante da natureza. Atualmente, aliás, não há outro pensamento político importante que rivalize com a ecologia. Às vezes o pensamento ecológico constitui-se, no entanto, numa utopia, não é aplicável, portanto não se constitui em uma visão política. A ecologia não é necessariamente realista, mas hoje não podemos fazer um projeto sem considerá-la, sem sonhar, sem refletir. Somos obrigados a projetar pensando num processo de gestão sustentável no tempo...

\section{A ação política deve estar aberta à ecologia?}

Sim, certamente. Atualmente, a ação política é forçosamente marcada pela ecologia. Mas a ecologia foi muito mal utilizada em ações equivocadas, ela foi muitas vezes mal utilizada pelos políticos. Atualmente, não é muito interessante declarar-se 'verde', declarar-se 'ecologista'...

\section{O senhor acredita que os usuários podem compreender as mensagens vinculadas nos jardins seriais e no Jardim do Movimento?}

De modo algum! Não nesse momento, mas isso não é grave! Existe muito conteúdo, muitas mensagens, é muito complexo... 
Isso me ajuda a conceber e a criar esses espaços. Por outro lado, eu estou convencido que as pessoas têm interesse nisso, mesmo que elas não compreendam a mensagem. $\bigcirc$ usuário sente certamente que existe ali alguma coisa que foi construída intelectualmente, mesmo que não saiba exatamente o quê. E eu penso que não é forçosamente necessário que os usuários compreendam de uma forma literal as mensagens vinculadas pelos conceptores. Eu acredito que eles sentem a importância desses espaços a partir de sua utilização cotidiana e banal. Isso é o que chamo de valor...

\section{Os jardins e os parques são também pedagógicos?}

Talvez não. Eu adoraria que os usuários compreendessem as mensagens vinculadas no projeto, mas o fato de querer obrigálos a entender me parece exagerado. Deve-se preservar o direito daqueles que utilizam um espaço sem compreendê-lo. Mas há usuários que desejam compreender, querem saber mais. Por isso acho importantes as publicações que expliquem o conteúdo dos jardins àqueles que assim o desejarem. Solicitei à Prefeitura de Paris que se responsabilizasse por isso, mas não fui atendido na minha solicitação."

\section{À Guisa de Conclusão}

O século 19 é o período em que emerge a idéia do parque público urbano. Atribui-se, então, a esse espaço um conjunto de qualidades que deveriam resolver os males da nascente civilização industrial. As doutrinas higienistas são, portanto, as primeiras a legitimar a função sanitária do parque urbano. Aos benefícios sanitários da natureza vão se juntar uma virtude "pacificadora", associada rapidamente a uma idéia de controle social. $\bigcirc$ parque público e seus usos deveriam servir de modelo para os mais pobres, ensinando-os relações de boas maneiras e cortesia.

Esses valores originais foram modificados no momento atual? Esse conjunto de virtudes, fortemente associado ao contexto da cidade do século 19, ainda é pertinente? Reencontraremos nos parques de La Villette, Bercy e AndréCitroën a encarnação desses valores de mais de um século? $\bigcirc$ exemplo do Parque André-Citroën, analisado no presente trabalho, parece validar a hipótese que, sob outras formas e com outras palavras, reencontramos a mesma simbologia nos parques atuais. A ecologia e a "cidade sustentável" substituíram as preocupações dos grandes reformadores do século 19. Mas os parques conservam ainda seus valores ancestrais, transmutados em outras formas, já que as qualidades higienistas, estéticas e hedonistas do parque público permanecem atuais. 


\section{Bibliografia}

BELMESSOUS, Hacène. Les à-côtés de la rénovation parisienne. Urbanisme, Paris, n. 310, p. 79-82, 2000.

CLÉMENT, Gilles; BERGER, Patrick; PROVOST, Alain; VIGUIER, Jean-Paul. Un jardin du XXème siècle à Paris, dialogue dans le Parc André Citroën. Entrevista a $S$. Andreu, France Culture-Le ler Fevrier 1993. Transcrito pela Biblioteca do Pavilhão do Arsenal, documento mimeografado, 5 fev. 1993.

CLÉMENT, Gilles. Éloge de la friche, aux pointes sèches de François Béalu. Paris: Lacourrière et Frélant, 1994.

. Traité succint de l'art involuntaire. Paris: Sens \& Tonka, 1997. . Les portes. Paris: Sens \& Tonka, 1998. . Le jardin en mouvement. Paris: Sens \& Tonka, 1999. . Les jardins planétaires. Paris: J.-M. Place, 1999.

Éloge des vagabondes - Herbes, arbres et fleurs à la conquête du monde. Paris: Nil éditions, 2002.

DEBIÉ, Franck. Jardins de capitales - Une géographie des parcs et jardins publics de Paris, Londres, Vienne et Berlin. Paris: Éditions du CNRS, 1992.

GARCIAS, Jean-Claude. Un lustre après, le concours Citroën revisité. Paris Projet, Paris, n. 30-31, p. 100-114, 1993.

INGALINA, Patrizia. Paris: Jardins d'hier, jardins d'aujourd'hui. LIGEIA - Dossiers sur I'art, Paris, n. 19-20, p. 87-91, 1997.

LACOSTE, Gérard. Le devenir du logement social. Urbanisme, Paris, n. 310, p. $76-$ 79, 2000.

LEMONIER, Marc. Un grand parc ouvert la nuit. Diagonal, n. 112, p. 32-33, 1995.

MILLIEX, Jean-Michel. Le parc André-Citroën et son quartier. Paris Projet, Paris, n. 30-31, p. 90-95, 1993.

PROKSCH, Thomas. Park-en. Stehenbleiben bei einigen Gedanken zum Thema Park. Zolltexte, n. 4, p. 28-31, 1992.

RACINE, Michel. Jardins en France, Guide llustré. 3. éd. Arles: Actes Sud, 1999.

RUEFF, Judith. Le retour de l'esprit jardin - André-Citroën, le nouveau parc où la tradition refleurit. Urbanisme, Paris, n. 264-265, p. 45-47, 1993.

SERPA, Angelo. Parque público e valorização imobiliária nas cidades contemporâneas: Tendências recentes na França e no Brasil. In: X ENCONTRO NACIONAL DA ANPUR: ENCRUZILHADAS DO PLANEJAMENTO - REPENSANDO TEORIAS E PRÁTICAS. 2003, Belo Horizonte. Anais... Belo Horizonte: ANPUR/UFMG, 2003, CD-ROM.

STARKMAN, Nathan. Deux nouveaux parcs à Paris. Paris Projet, Paris, n. 30-31, p. 88-89, 1993.

SURAND, Guy. Un parc pour le XXlème siècle. Paysage et Actualités. Paris, p. IV-VIII, oct. 1992. 